Article

\title{
Lysimeter-Based Water Use and Crop Coefficient of Drip-Irrigated Potato in an Arid Environment
}

\author{
Abed Alataway ${ }^{1, *}$, Hussein Al-Ghobari ${ }^{2}$, Fawzi Mohammad ${ }^{2}$ and Ahmed Dewidar 1,2 \\ 1 Prince Sultan Bin Abdulaziz International Prize for Water Chair, Prince Sultan Institute for Environmental, \\ Water and Desert Research, King Saud University, Riyadh 11451, Saudi Arabia; adewidar@ksu.edu.sa \\ 2 Department of Agricultural Engineering, King Saud University, Riyadh 11451, Saudi Arabia; \\ hghobari@KSU.EDU.SA (H.A.-G.); fdeeb111@gmail.com (F.M.) \\ * Correspondence: aalataway@ksu.edu.sa; Tel.: +96-601-146-75576
}

Received: 3 August 2019; Accepted: 8 November 2019; Published: 14 November 2019

check for updates

\begin{abstract}
The determination of the water requirements and crop coefficient $\left(\mathrm{K}_{\mathrm{c}}\right)$ of agricultural crops helps to create an appropriate irrigation schedule, and with the effective management of irrigation water. The aim of this research was to estimate the water requirement, $K_{c}$, and water-use efficiency (WUE) of potato using non-weighing-type lysimeters in four regions of the Kingdom of Saudi Arabia (Qassiem, Riyadh, Al-Jouf, and Eastern). Our results clearly show that the accumulated values of the measured crop evapotranspiration of potato derived from the lysimeters were 573, 554,592 , and $570 \mathrm{~mm}$, while the accumulated values of the predicted crop evapotranspiration from Penman-Monteith equation based on FAO (Food and Agriculture Organization) were 651, 632, 672, and $647 \mathrm{~mm}$ for the Qassiem, Riyadh, Al-Jouf, and Eastern regions, respectively. The $\mathrm{K}_{\mathrm{c}}$ values of potato obtained from the lysimeters were $\mathrm{K}_{\mathrm{c}}$ initial $(0.58,0.54,0.50$, and 0.52$), \mathrm{K}_{\mathrm{c}}$ middle $(1.02,1.05$, 1.13 , and 1.10), and $\mathrm{K}_{\mathrm{c}}$ end $(0.73,0.74,0.74$, and 0.75) for the Qassiem, Riyadh, Al-Jouf, and Eastern regions, respectively. Based on the amount of water used and the yield achieved, the highest WUE $\left(3.6 \mathrm{~kg} \mathrm{~m}^{-3}\right)$ was observed in the Riyadh region, while the lowest WUE $\left(1.5 \mathrm{~kg} \mathrm{~m}^{-3}\right)$ was observed in the Al-Jouf region.
\end{abstract}

Keywords: crop coefficient; crop evapotranspiration; lysimeter; reference evapotranspiration; water use efficiency

\section{Introduction}

In agriculture, a precise estimate of both the crop evapotranspiration (ET) and reference evapotranspiration $\left(\mathrm{ET}_{\mathrm{o}}\right)$ is indispensable for determining crop water requirements, irrigation scheduling, irrigation system designs, and hydrological studies [1]. ET is defined as the sum of evaporation from soil and transpiration from plants [2].

Micrometeorological approaches, like the Eddy covariance and Bowen ratio techniques, have been widely used in recent times for indirectly measuring ET [3-7]. On the other hand, lysimeters are still the standard method for directly measuring ET [8].

Based on the available resources and necessity, lysimeters in different sizes and types are designed to study the water and solute transport [9], as well as ET rates [10-13]. The shapes of lysimeters are varied, including a rectangular shape [14-18], circular shape [19-21], and square shape [22,23]. Furthermore, researchers use another type of lysimeter with a small area of $0.006 \mathrm{~m}^{2}$, usually known as a microlysimeter, in order to measure the evaporation of soil water [24].

Another classification of lysimeters is dependent on how the soil is collected inside the lysimeters. In other words, lysimeters can be repacked, monolithic, or a combination of repacked and monolithic [25]. In repacked lysimeters, the soil within the lysimeter is disturbed soil that is repacked to imitate the 
features of the intact soil $[19,21]$. In monolithic lysimeters, the soil inside the lysimeter is intact soil $[15,20,22,26]$.

Lysimeters can be weighing and non-weighing. Weighing lysimeters measure the crop ET directly by estimating the change in mass of an isolated soil volume [25]. The non-weighing lysimeters, on the other hand, measure the crop ET by estimating the soil water balance components, including water inputs (irrigation), water outputs (drainage), and changes in soil water storage [27].

Potato production (Solanum tuberosum L.) takes an imperative place in the world's agriculture, with a global production of about 327 million tharvested, and an area of 18.6 million ha [28]. Potatoes are highly sensitive to moisture stress, as $85 \%$ of their root system is settled in the upper $0.30 \mathrm{~m}$ of the soil layer [29]. For potato irrigation, drip irrigation is one of the best methods for row crop production, because of its effect on minimizing the evaporation from soil water, reducing the leaching of fertilizers, and improving the yield $[29,30]$.

Potatoes of 120 to 150 days consume 500 to $700 \mathrm{~mm}$ of irrigation water, depending on the climate [1]. For example, Kashyap and Panda [31] found that the average value of ET for potato was $509 \mathrm{~mm}$ in a sub-humid area of India under furrow irrigation conditions. On the other hand, under hot dry conditions and sprinkler irrigation system in northeastern Portugal, the water requirement for potato reached $569 \mathrm{~mm}$ [32]. Another example of dry areas, such as Wadi Sirhan, Al-Jouf (Saudi Arabia), Al-Rumkhani and Din [33] found that the water requirement for potato was $652 \mathrm{~mm}$.

The crop coefficient, $\mathrm{K}_{\mathrm{c}}$, is the ratio of $\mathrm{ET}$ to $\mathrm{ET}_{\mathrm{o}}$ [1]. $\mathrm{K}_{\mathrm{c}}$ represents the integration of the impacts of three basic characteristics that recognize the crop from the reference $\mathrm{ET}_{\mathrm{o}}$. These characteristics are as follows: crop-soil surface resistance, crop height, and albedo of the crop-soil surface [1]. Several researchers have assigned different values of $K_{c}$ for potato [34]. For example, Ferreira and Carr [32] showed that the seasonal $K_{c}$ values of potato ranged from 0.50 to 0.85 . The $K_{c}$ values of potatoes based on the FAO (Food and Agriculture Organization) results during the initial stage, mid stage, and end stage are $0.50,1.15$, and 0.75 , respectively [1].

Water-use efficiency (WUE) is another essential factor in irrigation systems and water management [35]. In most agricultural studies, the WUE is determined as the total production of the aboveground biomass per amount of water used [36]. An example of the importance of WUE in water management is what Pereira et al. [37] reported, where they developed a deficit irrigation strategy based on the economic indicators for WUE and productivity, which takes into account the full awareness of the crop water requirements. The goal of this work was, over a three-season period, (1) to estimate the irrigation requirements, $\mathrm{K}_{\mathrm{c}}$, and WUE of potato crop in four regions of the Kingdom of Saudi Arabia, and (2) to assess the potential economic returns of potato production.

\section{Materials and Methods}

\subsection{Descriptions of the Study Sites}

The field experiments were carried out at (Qassiem University, Qassiem, Saudi Arabia), (Ministry of Agriculture, Riyadh, Saudi Arabia), (Alwatania Agricultural Company, Al-Jouf, Saudi Arabia), and (King Faisal University, Eastern, Saudi Arabia) regions. The geographical coordinates and locations of the four regions of the Kingdom of Saudi Arabia (KSA) are presented in Table 1. The average values of the annual rainfall in the KSA ranges between 80 and $140 \mathrm{~mm}$, except for in the southwestern mountains [38]. The average values for the temperatures in the Qassiem, Riyadh, Al-Jouf, and Eastern regions were $35,36,33$, and $37^{\circ} \mathrm{C}$, respectively. The relative humidity was low, and the average values for the relative humidity were $12 \%, 13 \%, 17 \%$, and $24 \%$ in the Qassiem, Riyadh, Al-Jouf, and Eastern regions, respectively. Other meteorological data for each area of the four regions are illustrated in Figure 1. 
Table 1. The geographical coordinates of the experimental locations at the four regions of the Kingdom of Saudi Arabia (KSA).

\begin{tabular}{ccccc}
\hline Location & Longitude & Latitude & Altitude (m) & Region \\
\hline $\mathrm{QU}$ & $43^{\circ} 46^{\prime} \mathrm{E}$ & $26^{\circ} 21^{\prime} \mathrm{N}$ & 648 & Qassiem \\
$\mathrm{MOA}$ & $46^{\circ} 43^{\prime} \mathrm{E}$ & $24^{\circ} 43^{\prime} \mathrm{N}$ & 600 & Riyadh \\
$\mathrm{AAC}$ & $39^{\circ} 29^{\prime} \mathrm{E}$ & $29^{\circ} 29^{\prime} \mathrm{N}$ & 724 & Al-Jouf \\
$\mathrm{KFU}$ & $49^{\circ} 33^{\prime} \mathrm{E}$ & $25^{\circ} 21^{\prime} \mathrm{N}$ & 179 & Eastern \\
\hline
\end{tabular}

QU—Qassiem University; MOA—Ministry of Agriculture; AAC—Alwatania Agricultural Company; KFU—King Faisal University.
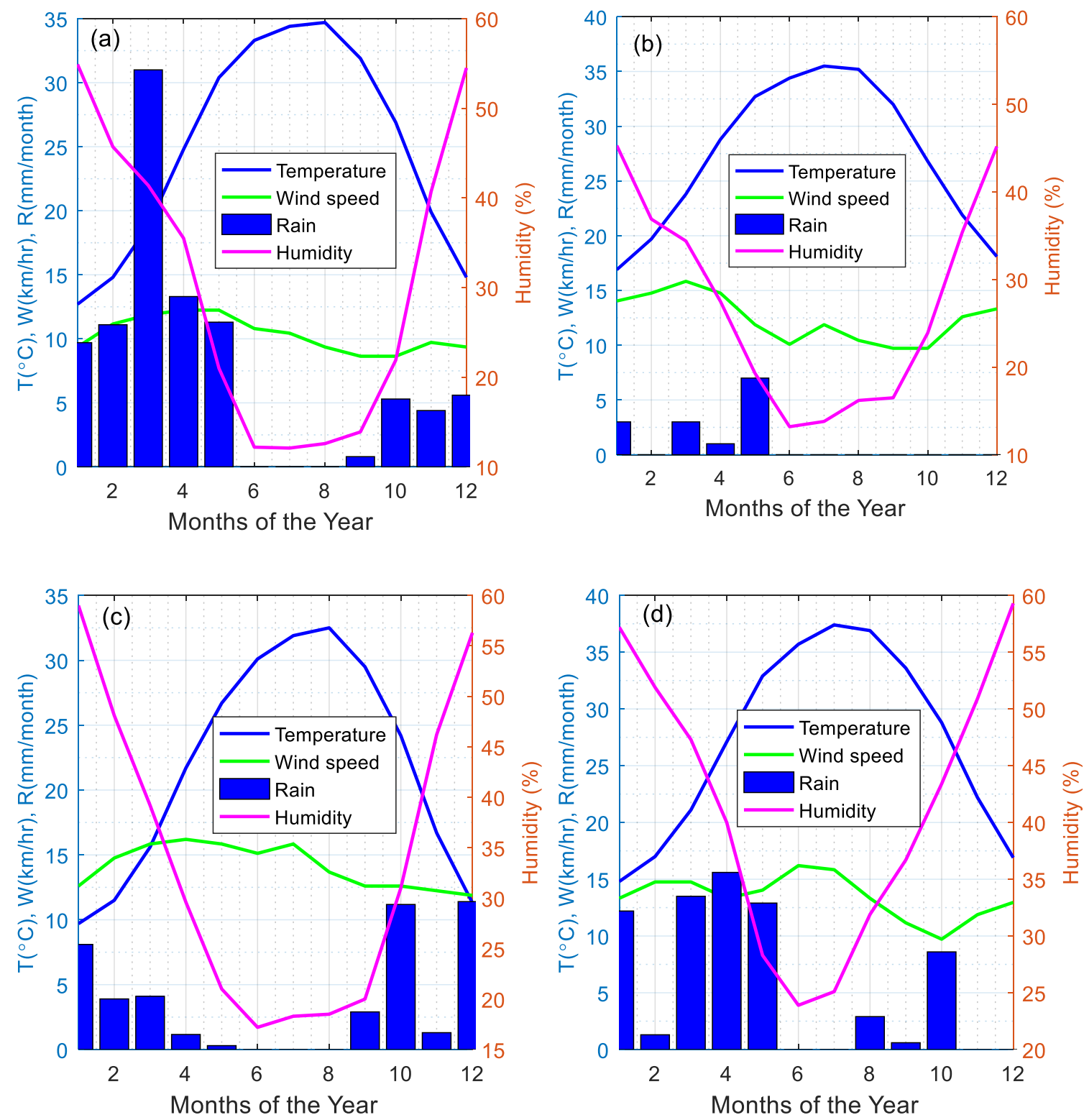

Figure 1. Average monthly climatic data for the: (a) Qassiem area, (b) Riyadh area, (c) Al-Jouf area, and (d) Eastern area of the Kingdom of Saudi Arabia (KSA). T is the temperature $\left({ }^{\circ} \mathrm{C}\right), \mathrm{W}$ is the wind speed $(\mathrm{km} / \mathrm{h})$, and $\mathrm{R}$ is the rainfall ( $\mathrm{mm} / \mathrm{month})$.

\subsection{Lysimeters}

Two non-weighing lysimeters were designed to grow alfalfa (Mcdicago sativa) and potatoes (Solanum tuberosum L.) in four regions of KSA (Qassiem, Riyadh, Al-Jouf, and Eastern; Figure 2). 
The lysimeters were used to obtain the measured crop evapotranspiration $\left(\mathrm{MET}_{\mathrm{c}}\right)$, measured reference evapotranspiration $\left(\mathrm{MET}_{\mathrm{r}}\right)$, and crop coefficient of potatoes. Lysimeters were filled with repacked soil, which imitates the features of the native soil. A 15-cm-thick layer of graded gravel was placed at the bottom of the lysimeters plots so as to facilitate the drainage process. An underground passageway was constructed to easily collect the drained water. The alfalfa and potato crops in both lysimeters were irrigated by sprinkler and drip irrigation systems, respectively, as were the crops in the surrounding areas, so as to avoid any potential discrepancies in the estimation process.

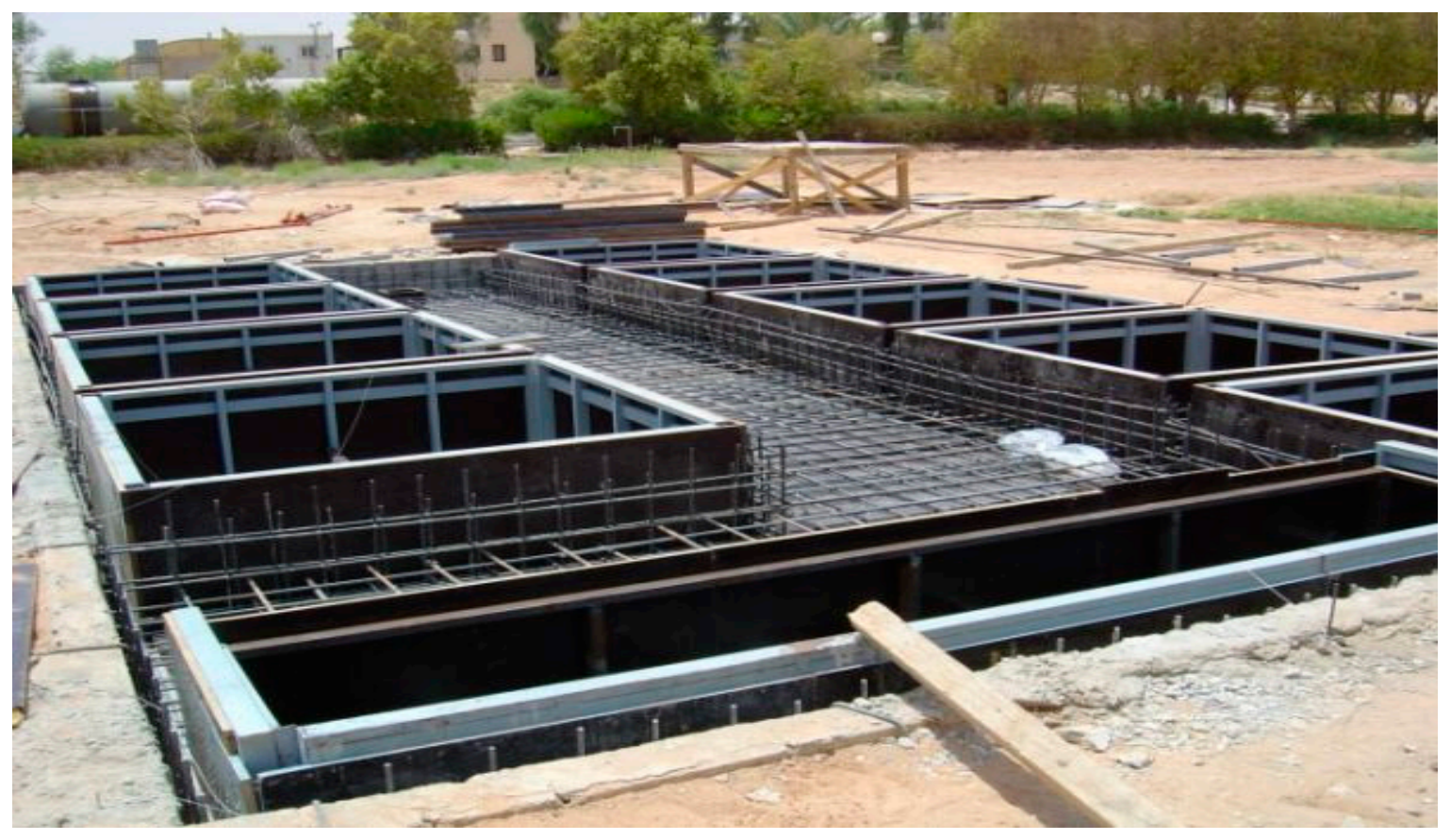

Figure 2. Constructing the lysimeter at the experimental field.

\subsection{Prediction of the Reference Evapotranspiration}

The lysimeters grown with alfalfa at the four regions were irrigated daily, with various amounts of water according to the reference evapotranspiration $\left(\mathrm{ET}_{\mathrm{o}}\right)$ acquired from a nearby weather station (Equation (1)). Similarly, the lysimeters cultivated with potatoes at the four regions were irrigated on a daily basis, according to the $\mathrm{ET}_{\mathrm{o}}$ values and FAO (Food and Agriculture Organization) crop coefficients [1]. The amounts of irrigation and drainage water were measured after each irrigation event, where the lysimeters were fitted with suitable inlets for irrigation and outlets for drained water.

$$
\mathrm{ET}_{\mathrm{o}}=\frac{0.408 \Delta\left(\mathrm{R}_{\mathrm{n}}-\mathrm{G}\right)+\gamma\left[\frac{\left(900 \mathrm{U}_{2}\right)}{\mathrm{T}+237}\right]\left(\mathrm{e}_{\mathrm{s}}-\mathrm{e}_{\mathrm{a}}\right)}{\Delta+\gamma\left(1+0.34 \mathrm{U}_{2}\right)}
$$

where $\mathrm{ET}_{\mathrm{o}}$ is the daily reference crop evapotranspiration rate $\left(\mathrm{mm} /\right.$ day), $\mathrm{R}_{\mathrm{n}}$ is the net radiation at the canopy surface $\left(\mathrm{MJ} / \mathrm{m}^{2} / \mathrm{d}\right), \mathrm{G}$ is the soil heat flux at the soil surface $\left(\mathrm{MJ} / \mathrm{m}^{2} / \mathrm{d}\right), \mathrm{T}$ is the mean daily air temperature $\left({ }^{\circ} \mathrm{C}\right), \gamma$ is the psychometric constant $\left(\mathrm{kPa} /{ }^{\circ} \mathrm{C}\right), \mathrm{U}_{2}$ is the mean daily wind speed at a height of $2.0 \mathrm{~m}(\mathrm{~m} / \mathrm{s}), e_{s}$ is the mean saturation vapor pressure $(\mathrm{kPa}), \mathrm{e}_{\mathrm{a}}$ is the mean actual vapor pressure $(\mathrm{kPa}),\left(\mathrm{e}_{\mathrm{s}}-\mathrm{e}_{\mathrm{a}}\right)$ is the saturated vapor pressure deficit $(\mathrm{kPa})$, and $\Delta$ is the slope of the saturated vapor pressure temperature curve $\left(\mathrm{kPa} /{ }^{\circ} \mathrm{C}\right)$.

\subsection{Crop Data}

Alfalfa (Mcdicago sativa) and potato (Solanum tuberosum L.) were cultivated in the plots of the first and second lysimeters, respectively, at the four regions of KSA over a three-season period (2012 to 2015). 
The conditions surrounding the alfalfa plots were similar to the standard conditions (height of $0.12 \mathrm{~m}$, surface resistance of $70 \mathrm{~s} \mathrm{~m}^{-1}$, and an albedo of 0.23) of the Penman-Monteith equation. Nutrients $\mathrm{N}, \mathrm{P}$, and K were delivered to potatoes at rates of 200, 200, and $150 \mathrm{~kg} / \mathrm{ha}$, respectively, in accordance with the recommendations set out by the Ministry of Agriculture. Pesticides were used whenever needed so as to control insects and pathogens. The fungicide Penncozeb 75 DG and Imidor 200SL (Astra Agricultural Co. Ltd., Riyadh, Saudi Arabia) were applied at a rate of $2.5 \mathrm{~g} / \mathrm{L}$ and $0.5 \mathrm{~mL} / \mathrm{L}$, respectively, for all of the treatments at the four regions. The potatoes were planted on $15 \mathrm{March}$ in the four regions, while 28 July was the date of harvesting in the four regions. The average yields of the potatoes for the Qassiem, Riyadh, Al-Jouf, and Eastern regions were $24.40 \mathrm{t} \mathrm{ha}^{-1}, 26.97 \mathrm{t} \mathrm{ha}^{-1}$, $17.69 \mathrm{tha}^{-1}$, and $18.25 \mathrm{tha}^{-1}$, respectively.

\subsection{Crop Coefficient}

$\mathrm{K}_{\mathrm{c}}$ is the ratio of the well-watered crop evapotranspiration and reference evapotranspiration (i.e., $\mathrm{MET}_{\mathrm{c}} / \mathrm{MET}_{\mathrm{r}}$ ) [1]. The $\mathrm{K}_{\mathrm{c}}$ values reflect the relative water consumption capacity of a specific crop during the different growing stages. The $\mathrm{K}_{\mathrm{c}}$ curve is divided into four stages-the initial, development, mid-season, and late season periods. Three values are required to generate the $\mathrm{K}_{\mathrm{c}}$ curve, namely the $\mathrm{K}_{\mathrm{c}}$ during the initial period $\left(\mathrm{K}_{\mathrm{c} \text { ini }}\right)$, the $\mathrm{Kc}_{\mathrm{c}}$ during the mid-season $\left(\mathrm{K}_{\mathrm{c} \text { mid }}\right)$, and the $\mathrm{K}_{\mathrm{c}}$ at the late season $\left(\mathrm{K}_{\mathrm{c} \text { end }}\right)$.

\subsection{Water-Use Efficiency}

WUE is defined as the total production of the biomass aboveground per amount of water used [39], as follows:

$$
\mathrm{WUE}=\sum_{\mathrm{i}=1}^{\mathrm{n}}[(\mathrm{y}) /(\mathrm{wa})]
$$

where WUE is the water-use efficiency $\left(\mathrm{kg} / \mathrm{m}^{3}\right), \mathrm{n}$ is the number of plots with each irrigation strategy, $\mathrm{y}$ is the total yield $(\mathrm{kg})$, and wa is the amount of seasonally applied water $\left(\mathrm{m}^{3}\right)$.

\subsection{Economic Analysis}

The economic potential of the production of irrigated potatoes was investigated through the following two perspectives:

1. The estimated net return;

2. The return from water use.

The economic analysis included the water requirements $\left(\mathrm{m}^{3} \mathrm{ha}^{-1}\right)$, area productivities $\left(\mathrm{t} \mathrm{ha}^{-1}\right)$, water costs (US $\$ \mathrm{~m}^{-3}$ ), variable costs (US $\$ \mathrm{ha}^{-1}$ ), market prices (US $\$ \mathrm{t}^{-1}$ ), net return (US $\$ \mathrm{ha}^{-1}$ ), economic return (US $\$ \mathrm{ha}^{-1}$ ), and water return $\left(\mathrm{US} \$ \mathrm{~m}^{-3}\right.$ ).

\section{Results and Discussion}

\subsection{The Reference Evapotranspiration}

Figure 3 shows the measured evapotranspiration of the alfalfa $\left(\mathrm{MET}_{\mathrm{r}}\right)$ acquired from the lysimeters for the studied locations (Qassiem, Riyadh, Al-Jouf, and Eastern) of KSA. As can be seen from Figure 3, the values of $\mathrm{MET}_{\mathrm{r}}$ were relatively low during the growth stage, then it increased gradually and peaked over the flowering stage. For example, the average values of $\mathrm{MET}_{\mathrm{r}}$, which were derived from the lysimeters, were $2.16,2.10,2.64$, and $2.4 \mathrm{~mm} /$ day in the initial stage; $5.46,5.10,5.11$, and $5.22 \mathrm{~mm} /$ day in the mid-season stage, and 5.28, 4.98, 4.87, and $4.85 \mathrm{~mm} /$ day in the late stage for the Qassiem, Riyadh, Al-Jouf, and Eastern regions, respectively. 

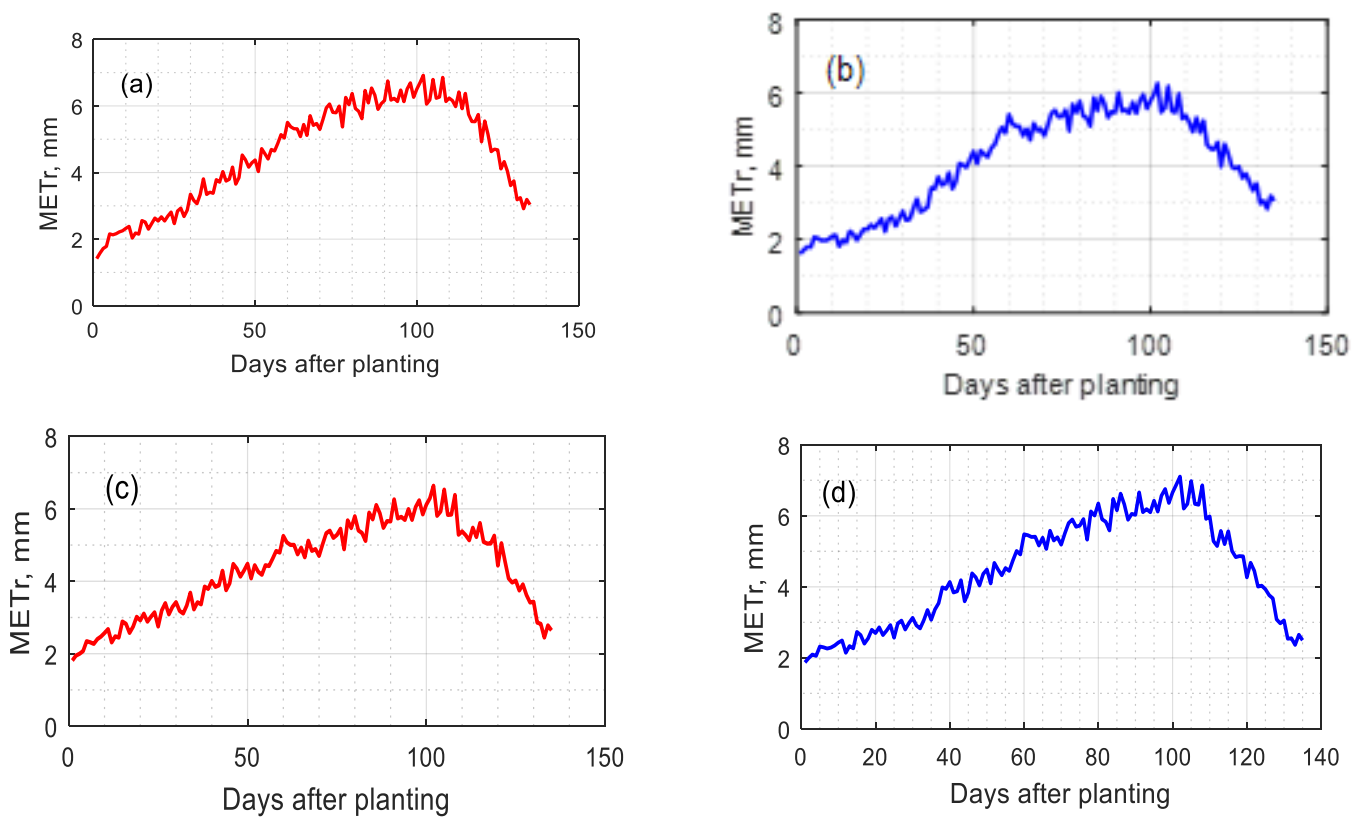

Figure 3. Measured evapotranspiration of the alfalfa $\left(\mathrm{MET}_{\mathrm{r}}\right)$ at the: (a) Qassiem area, (b) Riyadh area, (c) Al-Jouf area, and (d) Eastern area of the Kingdom of Saudi Arabia (KSA).

\subsection{The Crop Evapotranspiration}

Figure 4 illustrates the measured crop evapotranspiration $\left(\mathrm{MET}_{\mathrm{c}}\right)$ gained from the lysimeters on the one hand, and the predicted crop evapotranspiration $\left(\mathrm{PET}_{\mathrm{C}}\right)$ acquired from a nearby weather station for potato crop, on the other hand, in the four regions of KSA. The values of $\mathrm{MET}_{\mathrm{c}}$ and $\mathrm{PET}_{\mathrm{c}}$ varied from a low of 1.92 and $1.95 \mathrm{~mm} /$ day in the Riyadh, respectively, during the germination stage, to a high of 12.1 and $15.2 \mathrm{~mm} /$ day in Al-Jouf region over the flowering stage. The average values of the $\mathrm{MET}_{\mathrm{c}}$ for the Qassiem, Riyadh, Al-Jouf, and Eastern regions were 1.26, 1.14, 1.32, and $1.26 \mathrm{~mm} /$ day; 5.58, $5.40,5.76$, and $5.74 \mathrm{~mm} /$ day; and 3.90, 3.72, 3.60, and $3.66 \mathrm{~mm} /$ day in the initial stage, the mid-season stage, and the late season periods, respectively. Similarly, the values of $\operatorname{PET}_{\mathrm{c}}$ were 1.38, 1.26, 1.50, and $1.38 \mathrm{~mm} /$ day in the initial stage; $8.46,8.40,9$, and $8.82 \mathrm{~mm} /$ day in the mid-season stage; and 4.56, $4.38,4.20$, and $4.26 \mathrm{~mm} /$ day in the late season stage for the Qassiem, Riyadh, Al-Jouf, and Eastern regions, respectively. Overall, the measured values, $\mathrm{MET}_{\mathrm{c}}$, were somewhat close to the predicted values, $\mathrm{PET}_{\mathrm{c}}$. However, the values of $\mathrm{PET}_{\mathrm{c}}$ were slightly higher than the values of $\mathrm{MET}_{\mathrm{c}}$. These results are in agreement with the literature [40,41].

\subsection{Crop Coefficient of Potato}

Figure 5 shows the $\mathrm{K}_{\mathrm{c}}$ values of the potato crop obtained from lysimeters (i.e., $\mathrm{MET}_{\mathrm{c}}$ and $\mathrm{MET}_{\mathrm{r}}$ ) at the four regions of KSA. The values measured from the lysimeters were $\mathrm{K}_{\mathrm{c} \text { ini }} 0.58,0.54,0.50$, and 0.52; $\mathrm{K}_{\mathrm{c} \text { mid }} 1.02,1.05,1.13$, and 1.10; and $\mathrm{K}_{\mathrm{c} \text { end }}: 0.73,0.74,0.74$, and 0.75 for the Qassiem, Riyadh, Al-Jouf, and Eastern regions, respectively. It can be noted that the $\mathrm{K}_{\mathrm{c}}$ values were relatively low at the initial stage, mainly because the evapotranspiration at this stage depended on the evaporation from the soil, as the crop had no ground cover. On the other hand, the highest values of $K_{c}$ were found within the mid-season stage, as the evapotranspiration was significantly high. At the late stage period, the $\mathrm{K}_{\mathrm{c}}$ values decreased steadily because of the maturity and senescence of the leaves. Compared to the FAO (Food and Agriculture Organization) results, the obtained $\mathrm{K}_{\mathrm{c}}$ values were similar to what the FAO recommends [1]. 

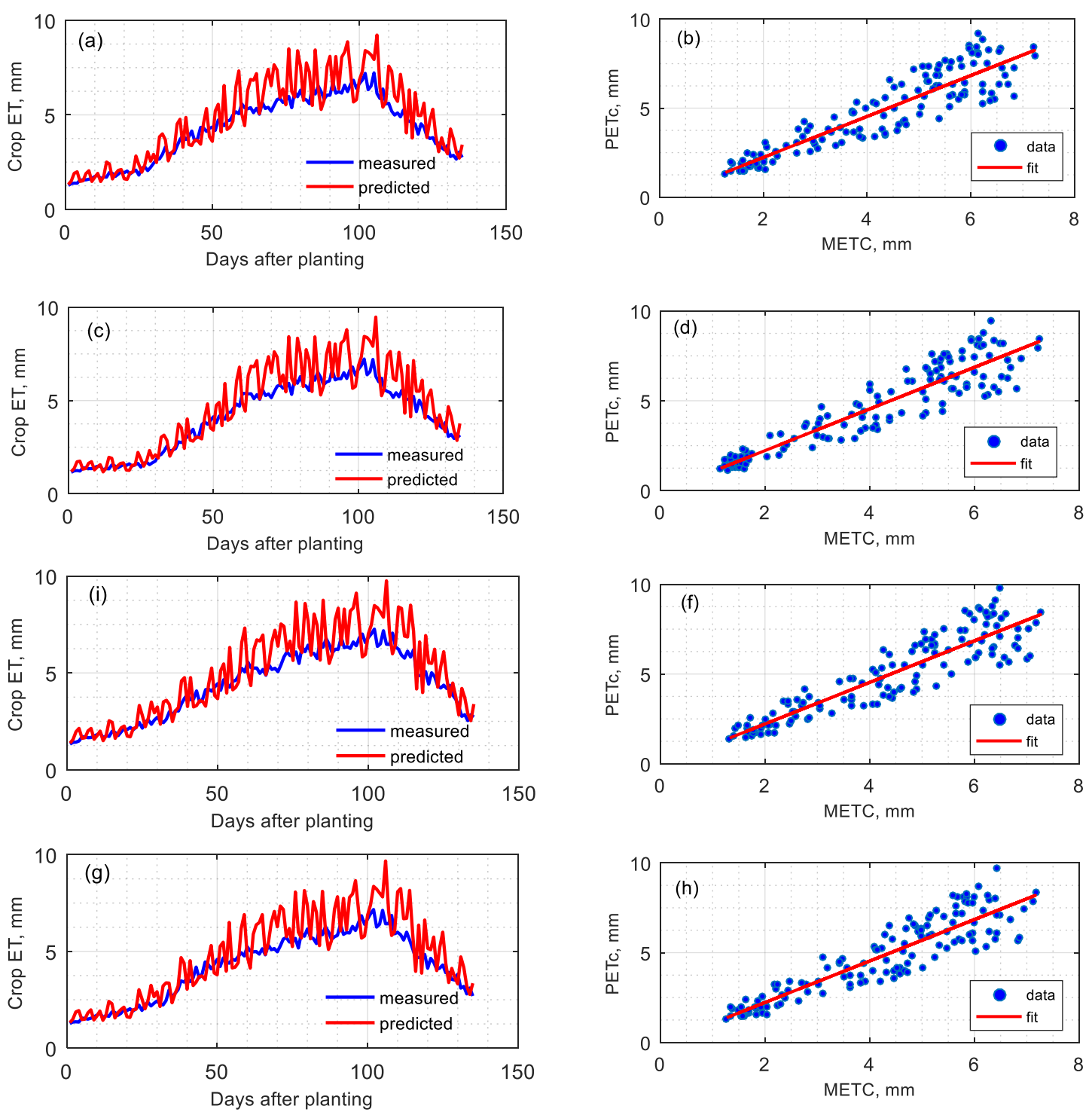

Figure 4. The left-hand panel (a,c,i,g) shows the crop evapotranspiration (crop ET) associated with days after planting at the: (a) Qassiem area, (c) Riyadh area, (i) Al-Jouf area, and (g) Eastern area of the Kingdom of Saudi Arabia (KSA). The right-hand panel $(\mathbf{b}, \mathbf{d}, \mathbf{f}, \mathbf{h})$ shows the measured crop evapotranspiration $\left(\mathrm{MET}_{\mathrm{C}}\right)$ and predicted crop evapotranspiration $\left(\mathrm{PET}_{\mathrm{C}}\right)$ of potato at the: $(\mathbf{b})$ Qassiem area, (d) Riyadh area, (f) Al-Jouf area, and (h) Eastern area of the KSA.

\subsection{Water-Use Efficiency (WUE)}

Figure 6 shows the WUE, which represents the relationship between the crop yield and quantity of water used at the four regions of KSA. The spatial patterns of the WUE were generally consistent with those of the yield and evapotranspiration (i.e., a high-yield was accompanied by a high WUE, and vice versa). For example, the drip-irrigated treatments in the Riyadh and Qassiem regions produced a higher WUE in comparison with those treatments irrigated in the Eastern and Al-Jouf regions. In other words, the highest WUE $\left(3.6 \mathrm{~kg} \mathrm{~m}^{-3}\right)$ was observed in the Riyadh region, while the lowest WUE $\left(1.5 \mathrm{~kg} \mathrm{~m}^{-3}\right)$ was observed in the Al-Jouf region. This was mainly because of the climatic conditions and different soil characteristics in each region. 

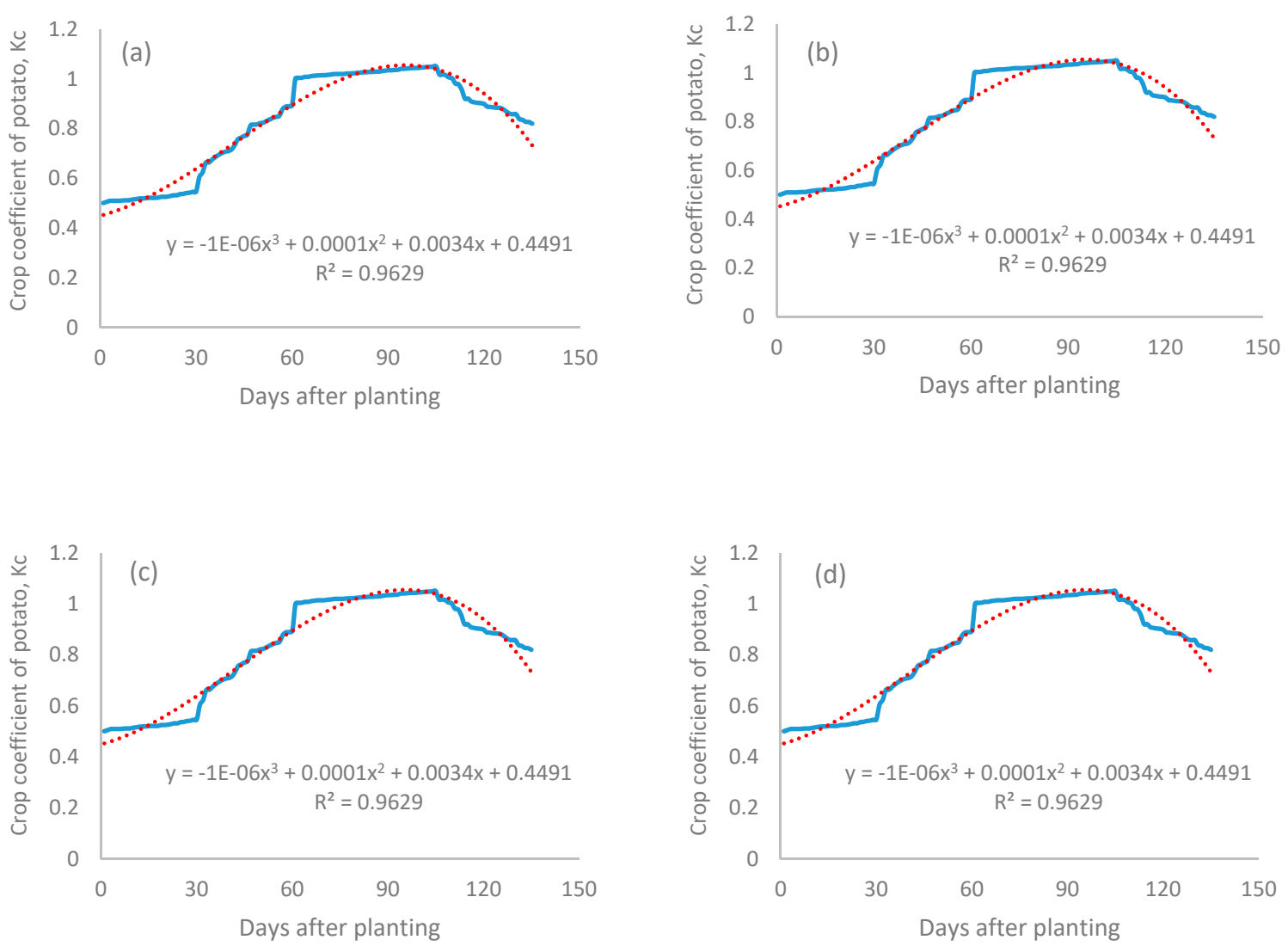

Figure 5. Crop coefficient, $\mathrm{K}_{\mathrm{c}}$, of the potato crop at the: (a) Qassiem area, (b) Riyadh area, (c) Al-Jouf area, and (d) Eastern area of the Kingdom of Saudi Arabia (KSA).

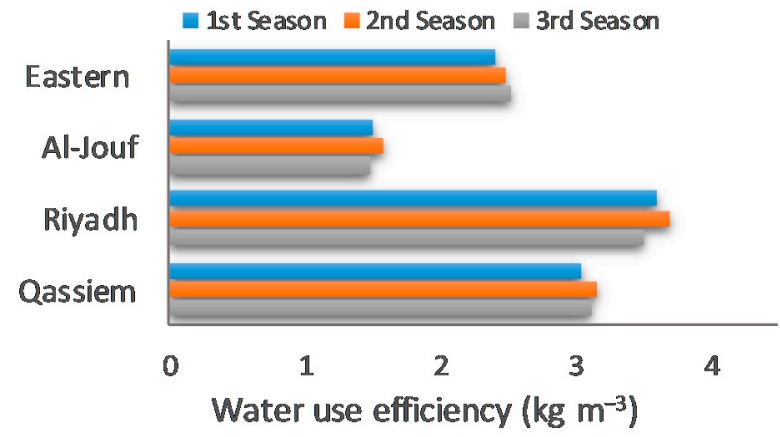

Figure 6. Water-use efficiency of the potato crop at the studied regions of KSA.

\subsection{Economic Analysis}

The economic analysis for the irrigated potatoes in the Qassiem, Riyadh, Al-Jouf, and Eastern regions are given in Table 2. As is clear from Table 2, the economic potential of the irrigated potato production is greatest in the Riyadh region, followed, in descending order, by the Qassiem, Eastern, and Al-Jouf regions. Also, the maximum value of the average water return was observed in the Riyadh region, while the minimum average value was noted in the Al-Jouf region. Furthermore, the average net return values for the irrigated potatoes were estimated as 7426.90 US $\$ \mathrm{ha}^{-1}, 4601.30 \mathrm{US} \$ \mathrm{ha}^{-1}$, 2202.70 US \$ ha ${ }^{-1}$, and 865.30 US \$ ha ${ }^{-1}$ for the Qassiem, Riyadh, Al-Jouf, and Eastern regions, respectively. This could be attributed to the changes in both the market prices and average variable costs at the study regions. 
Table 2. Economic potential of irrigated potato production at four regions of KSA.

\begin{tabular}{ccccc}
\hline \multirow{2}{*}{ Parameter } & \multicolumn{4}{c}{ Region } \\
\cline { 2 - 5 } & Qassiem & Riyadh & Al-Jouf & Eastern \\
\hline Average production $\left(\mathrm{t} \mathrm{ha}^{-1}\right)$ & 24.40 & 26.97 & 17.69 & 18.25 \\
Average water cost $\left(\$ \mathrm{~m}^{-3}\right)$ & 0.06 & 0.06 & 0.07 & 0.06 \\
Average market price $\left(\$ \mathrm{t}^{-1}\right)$ & 466.7 & 409.3 & 186.7 & 266.7 \\
Water requirement $\left(\mathrm{m}^{3} \mathrm{ha}^{-1}\right)$ & 11843 & 6712 & 8564 & 7130 \\
Average variable cost $\left(\$ \mathrm{ha}^{-1}\right)$ & 1089.6 & 5387.5 & 2831.3 & 3852.3 \\
Average return $\left(\$ \mathrm{ha}^{-1}\right)$ & 8516.8 & 9989.1 & 5033.8 & 4717.6 \\
Average net return $\left(\$ \mathrm{ha}^{-1}\right)$ & 7426.9 & 4601.3 & 2202.7 & 865.3 \\
Average water return $\left(\$ \mathrm{~m}^{-3}\right)$ & 0.72 & 1.49 & 0.59 & 0.67 \\
\hline
\end{tabular}

\section{Conclusions}

Two non-weighing lysimeters were designed to grow alfalfa (Mcdicago sativa) and potatoes (Solanum tuberosum L.) in four regions of the Kingdom of Saudi Arabia (Qassiem, Riyadh, Al-Jouf, and Eastern). The experiments were aimed at determining the irrigation requirements, $K_{c}$, and the economic returns of the potato crop. The results show that the accumulated values of the measured crop evapotranspiration obtained from the potato lysimeters were $573,554,592$, and $570 \mathrm{~mm}$ for the Qassiem, Riyadh, Al-Jouf, and Eastern regions, respectively. The $\mathrm{K}_{\mathrm{c}}$ values were $\mathrm{K}_{\mathrm{c} \text { ini }} 0.58,0.54,0.50$, and $0.52 ; \mathrm{K}_{\mathrm{c} \text { mid }} 1.02,1.05,1.13$, and 1.10; and $\mathrm{K}_{\mathrm{c} \text { end }} 0.73,0.74,0.74$, and 0.75 for the Qassiem, Riyadh, Al-Jouf, and Eastern regions, respectively. The average values of the water return for the irrigated potatoes at the Qassiem, Riyadh, Al-Jouf, and Eastern regions were estimated to be approximately $0.72 \$ \mathrm{~m}^{-3}, 1.49 \$ \mathrm{~m}^{-3}, 0.59 \$ \mathrm{~m}^{-3}$, and $0.67 \$ \mathrm{~m}^{-3}$, respectively.

Author Contributions: Conceptualization, A.A. and H.A.-G.; methodology, F.M. and H.A.-G.; formal analysis, A.A. and A.D.; writing (original draft), A.D.; writing (review and editing), all.

Funding: This research received no external funding.

Acknowledgments: This project was supported by the Vice Deanship of Research Chairs at King Saud University.

Conflicts of Interest: The authors declare that they have no conflicts of interest concerning this article.

\section{References}

1. Allen, R.G.; Pereira, L.S.; Raes, D.; Smith, M. Crop evapotranspiration-Guidelines for computing crop water requirements-FAO Irrigation and drainage paper 56. Faorome 1998, 300, D05109.

2. Rafi, Z.; Merlin, O.; Le Dantec, V.; Khabba, S.; Mordelet, P.; Er-Raki, S.; Amazirh, A.; Olivera-Guerra, L.; Hssaine, B.A.; Simonneaux, V.; et al. Partitioning evapotranspiration of a drip-irrigated wheat crop: Inter-comparing eddy covariance-, sap flow-, lysimeter-and FAO-based methods. Agric. For. Meteorol. 2019, 265, 310-326. [CrossRef]

3. Payero, J.O.; Neale, C.M.U.; Wright, J.L.; Allen, R.G. Guidelines for validating Bowen ratio data. Trans. Asae 2003, 46, 1051. [CrossRef]

4. Todd, R.W.; Evett, S.R.; Howell, T.A. The Bowen ratio-energy balance method for estimating latent heat flux of irrigated alfalfa evaluated in a semi-arid, advective environment. Agric. For. Meteorol. 2000, 103, 335-348. [CrossRef]

5. Verhoef, A.; Allen, S.J.; Lloyd, C.R. Seasonal variation of surface energy balance over two Sahelian surfaces. Int. J. Climatol. A J. R. Meteorol. Soc. 1999, 19, 1267-1277. [CrossRef]

6. Liu, J.; Kotoda, K. Estimation of regional evapotranspiration from arid and semi-arid surfaces 1. Jawra J. Am. Water Resour. Assoc. 1998, 34, 27-41. [CrossRef]

7. Laubach, J.; Raschendorfer, M.; Kreilein, H.; Gravenhorst, G. Determination of heat and water vapour fluxes above a spruce forest by eddy correlation. Agric. For. Meteorol. 1994, 71, 373-401. [CrossRef]

8. Allen, R.G.; Howell, T.A.; Pruitt, W.O.; Walter, I.A.; Jensen, M.E. Lysimeters for Evapotranspiration and envIronmental Measurements; American Society of Civil Engineers: New York, NY, USA, 1991; pp. 1-9. 
9. Robbins, C.W.; Willardson, L.S. An instrumented lysimeter system for monitoring salt and water movement. Trans. ASAE 1980, 23, 109-111. [CrossRef]

10. Goddard, W.B. A floating drag-plate lysimeter for atmospheric boundary layer research. J. Appl. Meteorol. 1970, 9, 373-378. [CrossRef]

11. Armijo, J.D.; Twitchell, G.A.; Burman, R.D.; Nunn, J.R. A large, undisturbed, weighing lysimeter for grassland studies. Trans. ASAE 1972, 15, 827-830. [CrossRef]

12. Dylla, A.S.; Cox, L.M. An Economical hydraulic weighing evapotranspiration tank. Trans. ASAE 1973, 16, 294-0295. [CrossRef]

13. LeDrew, E.F.; Emerick, J.C. A mechanical balance-type lysimeter for use in remote environments. Agric. Meteorol. 1974, 13, 253-258. [CrossRef]

14. Schneider, A.D.; Ayars, J.E.; Phene, C.J. Combining monolithic and repacked soil tanks for lysimeters from high water table sites. Appl. Eng. Agric. 1996, 12, 649-654. [CrossRef]

15. Malone, R.W.; Bonta, J.V.; Stewardson, D.J.; Nelsen, T. Error analysis and quality improvement of the Coshocton weighing lysimeters. Trans. ASAE 2000, 43, 271. [CrossRef]

16. Klocke, N.L.; Heermann, D.F.; Duke, H.R. Measurement of Evaporation and Transportation with Lysimeters. Trans. ASAE 1985, 28, 183-189. [CrossRef]

17. Tyagi, N.K.; Sharma, D.K.; Luthra, S.K. Determination of evapotranspiration for maize and berseem clover. Irrig. Sci. 2003, 21, 173-181.

18. Marek, T.; Piccinni, G.; Schneider, A.; Howell, T.; Jett, M.; Dusek, D. Weighing lysimeters for the determination of crop water requirements and crop coefficients. Appl. Eng. Agric. 2006, 22, 851-856. [CrossRef]

19. McFarland, M.J.; Worthington, J.W.; Newman, J.S. Design, installation and operation of a twin weighing lysimeter for fruit trees. Trans. ASAE 1983, 26, 1717-1721. [CrossRef]

20. Meshkat, M.; Warner, R.C.; Walton, L.R. Lysimeter design, construction, and instrumentation for assessing evaporation from a large undisturbed soil monolith. Appl. Eng. Agric. 1999, 15, 303. [CrossRef]

21. Yang, S.; Aydin, M.; Yano, T.; Li, X. Evapotranspiration of orange trees in greenhouse lysimeters. Irrig. Sci. 2003, 21, 145-149.

22. Marek, T.H.; Schneider, A.D.; Howell, T.A.; Ebeling, L.L. Design and construction of large weighing monolithic lysimeters. Trans. ASAE 1988, 31, 477-484. [CrossRef]

23. Schneider, A.D.; Howell, T.A.; Moustafa, A.T.A.; Evett, S.R.; Abou-Zeid, W. Asimplified Weighing Lysimeter for Monolithic or Reconstructed Soils. Appl. Eng. Agric. 1998, 14, 267-273. [CrossRef]

24. Evett, S.R.; Warrick, A.W.; Matthias, A.D. Wall material and capping effects on microlysimeter temperatures and evaporation. Soil Sci. Soc. Am. J. 1995, 59, 329-336. [CrossRef]

25. Payero, J.O.; Irmak, S. Construction, installation, and performance of two repacked weighing lysimeters. Irrig. Sci. 2008, 26, 191-202. [CrossRef]

26. Seyfried, M.S.; Hanson, C.L.; Murdock, M.D.; Van Vactor, S. Long-Term Lysimeter Database, Reynolds Creek Experimental Watershed, Idaho, United States. Water Resour. Res. 2001, 37, 2853-2856. [CrossRef]

27. Garcia, M.; Raes, D.; Allen, R.; Herbas, C. Dynamics of reference evapotranspiration in the Bolivian highlands (Altiplano). Agric. For. Meteorol. 2004, 125, 67-82. [CrossRef]

28. Ati, A.S.; Iyada, A.D.; Najim, S.M. Water use efficiency of potato (Solanum tuberosum L.) under different irrigation methods and potassium fertilizer rates. Ann. Agric. Sci. 2012, 57, 99-103. [CrossRef]

29. Wang, F.X.; Kang, Y.; Liu, S.P. Effects of drip irrigation frequency on soil wetting pattern and potato growth in North China Plain. Agric. Water Manag. 2006, 79, 248-264. [CrossRef]

30. Waddell, J.T.; Gupta, S.C.; Moncrief, J.F.; Rosen, C.J.; Steele, D.D. Irrigation and nitrogen management effects on potato yield, tuber quality, and nitrogen uptake. Agron. J. 1999, 91, 991-997. [CrossRef]

31. Kashyap, P.S.; Panda, R.K. Effect of irrigation scheduling on potato crop parameters under water stressed conditions. Agric. Water Manag. 2003, 59, 49-66. [CrossRef]

32. Ferreira, T.C.; Carr, M.K.V. Responses of potatoes (Solanum tuberosum L.) to irrigation and nitrogen in a hot, dry climate: I. Water use. Field Crop. Res. 2002, 78, 51-64. [CrossRef]

33. Al-Rumkhani, Y.A.; Din, S.U. Use of remote sensing for irrigation scheduling in arid lands of Saudi Arabia. J. Indian Soc. Remote Sens. 2004, 32, 225-233. [CrossRef]

34. Kashyap, P.S.; Panda, R.K. Evaluation of evapotranspiration estimation methods and development of crop-coefficients for potato crop in a sub-humid region. Agric. Water Manag. 2001, 50, 9-25. [CrossRef] 
35. Tallec, T.; Béziat, P.; Jarosz, N.; Rivalland, V.; Ceschia, E. Crops' water use efficiencies in temperate climate: Comparison of stand, ecosystem and agronomical approaches. Agric. For. Meteorol. 2013, 168, 69-81. [CrossRef]

36. Oberholzer, S.; Prasuhn, V.; Hund, A. Crop water use under Swiss pedoclimatic conditions-Evaluation of lysimeter data covering a seven-year period. Field Crop. Res. 2017, 211, 48-65. [CrossRef]

37. Pereira, L.S.; Cordery, I.; Iacovides, I. Improved indicators of water use performance and productivity for sustainable water conservation and saving. Agric. Water Manag. 2012, 108, 39-51. [CrossRef]

38. Alkolibi, F.M. Possible effects of global warming on agriculture and water resources in Saudi Arabia: Impacts and responses. Clim. Chang. 2002, 54, 225-245. [CrossRef]

39. Stanhill, G. Water use efficiency. Adv. Agron. 1986, 39, 53-85.

40. Al-Omran, A.M.; Shalaby, A.A. Calculation of water requirements for some crops in the eastern and central regions of the Kingdom of Saudi Arabia. J. Coll. Agric. King Saud Univ. 1992, 4, 97-114.

41. Al-Ghobari, H.M. Estimation of reference evapotranspiration for southern region of Saudi Arabia. Irrig. Sci. 2000, 19, 81-86. [CrossRef]

(C) 2019 by the authors. Licensee MDPI, Basel, Switzerland. This article is an open access article distributed under the terms and conditions of the Creative Commons Attribution (CC BY) license (http://creativecommons.org/licenses/by/4.0/). 